\title{
Refractions
}

\section{Breaking out of the Package: Educating literacy and numeracy teachers with agency}

\author{
KEIKO YASUKAWA
}

\begin{abstract}
What knowledge, skills and dispositions are needed by adult numeracy and literacy teachers to help their learners imagine and build better lives for themselves and sustainable futures for their children and community? What resources can teachers draw on to be able to exercise agency as a group of professionals to give voice to the needs and aspirations of their learners? Using the contemporary Australian adult numeracy and literacy context as a point of reflection, I argue that some degree of propensity to take risks is needed by teachers if they are to exercise agency as professional educators, and that the universities have a renewed role to play in creating spaces for educating risk-taking educators.
\end{abstract}

\section{Introduction}

Australian Bureau of Statistics data shows almost half of all working Australians have less than the minimum literacy and numeracy levels required to meet the demands of everyday work. (Harrison 2009)

Such was the way in which many people in Australia were informed by the media about the levels of adult literacy and numeracy in Australia at the start of National Literacy and Numeracy Week (NLNW) in 2009. Like many other OECD countries, Australia was part of the Adult Literacy and Life Skills Survey (ALLS) that was conducted in 2006 to measure the literacy and numeracy levels of adults (Australian Bureau of Statistics 2008). The results from the Survey, based on criteria developed by Statistics Canada and the OECD, do indeed suggest that over fifty percent of those Australians surveyed in ALLS have below the 'minimum required for individuals to meet the complex demands of everyday life and work in the emerging knowledge-based economy' (Statistics Canada cited in Australian Bureau of Statistics 2008:5). The statistics, even given the limitations of large scale surveys, could not be ignored by the Australian Federal Government, and one of its responses, announced at the start of NLNW, was to award 
half a million dollars to the Australian Industry Group, the peak industry employer association in Australia, to examine the literacy and numeracy issues more closely (Harrison 2009). It would be hard to criticise the provision of funding for a closer examination of the literacy and numeracy issues of the workplace. However, what is concerning many adult literacy and numeracy practitioners is the almost exclusive interest by the Government in the human capital dimensions of adult learning, with little apparent regard to the social and personal benefits that learning brings to many adults and their communities. As argued in Black and Yasukawa (this issue), adult literacy and numeracy in Australia is at the cross roads. There is an opportunity to influence the opening up of new spaces for reaching adults who can benefit from literacy and numeracy, influencing pedagogies in VET and investigating the benefits of literacy and numeracy through research.

There are also big challenges for the education and professional development of adult literacy and numeracy teachers. In particular, they relate to the competitive nature of the funding of adult literacy and numeracy programs that has recently resulted in the significant loss of provision in a number of the public providers (Job 2010). There is a high level of casualisation in the vocational education and training (VET) sector, over 56 per cent of practitioners according to 2008 figures (Nechvoglod, Mlotkowski and Guthrie 2010: 31). The LLN workforce within VET does not appear to be an exception. Mackay et al (2006), for example, found that only $31.8 \%$ of the adult LLN practitioners in their national study were permanent. As a representative of the national and state peak professional organisations for adult literacy and numeracy, and as a coordinator of a university-based adult literacy and numeracy teacher education program, I struggle to respond positively when prospective trainee-teachers ask me about career prospects in the adult LLN field. And similarly, when a newly qualified teacher asks what level of mentoring they can expect as a new casual teacher working in a highly casualised private college which has yet to establish a reputation as a quality adult literacy and numeracy provider.

In studying the professional development needs of LLN practitioners, Mackay et al (2006:21) found that time, funding constraints and the relationship between employment status and access to professional development were key barriers to professional development, and that teachers sought professional development in the form of short, practical, and hands-on sessions rather than formal qualifications. Moreover, although university qualifications have been the norm for adult LLN practitioners (McGuirk 2001), the number of university-based qualifications specifically in the area of adult literacy and numeracy 'has dwindled dramatically since the mid-1990s' (Innovation and Business Skills Australia 2010: 3). Against this 
backdrop, it is not surprising that the Australian Government supported the development within the VET system of a qualification that could be delivered by the VET sector and focused on meeting the immediate needs of the practitioners, rather than trying to renew the university sector's involvement in adult LLN teacher education.

These challenges, however, pose new challenges to the development of the future adult literacy and numeracy workforce. Where should education occur that focuses beyond the immediate hands-on, practical needs of the current policy environment and that seeks to engage practitioners in critical inquiry about their own professional practice and the direction in which their field is developing? I will argue here that the professional development of adult LLN practitioners should include the development of qualities of resilience, robustness and imagination, three of eight qualities that Claxton (1999 in Brown and Liebling 2005:181) identifies to improve people's capacity to learn.

\section{But it's all in the package!}

Since the mid 1980s, a competency-based paradigm of training and assessment has dominated the VET sector in Australia. VET programs are now derived from nationally endorsed competency-based industry training packages that can be defined as:

[a]n integrated set of nationally endorsed standards, guidelines and qualifications for training, assessing and recognising people's skills, developed by industry to meet the training needs of an industry or group of industries. Training packages consist of core endorsed components of competency standards, assessment guidelines and qualifications, and optional nonendorsed components of support materials such as learning strategies, assessment resources and professional development materials. (Naidu 2008:73)

Much debate continues about 'packaging' the training requirements of different industries in this way. One argument for this approach is that it makes the competency requirements for a trade or a vocation explicit, and not dependent on a particular course or the number of hours a person spends in training. If a person can demonstrate all the competencies for a trade according to the assessment guidelines, then they should be awarded the qualification through a process of RPL (Recognition of Prior Learning), irrespective of how they learned these competencies. There is undeniably much attraction and logic to this approach from the perspectives of the trainee, industry peak bodies, and the employers. If a person can demonstrate that they can 'do the job' that the employers need done, why 
waste everyone's time putting the person through expensive and timeconsuming courses?

But can adult educators' professional development be understood in the same way? The Australian Government recently initiated the development of training packages at VET Graduate Certificate and Diploma levels for Language Literacy and Numeracy (LLN) in order to increase the number and capacity of qualified adult LLN teachers and trainers. The training packages on the surface do consist of relevant skills for working in the adult LLN field, for example, units of competencies on analysing and applying adult LLN teaching practices in the VET contexts; designing and implementing assessment; and implementing and evaluating LLN programs (Innovation and Business Skills Australia 2010). However, there are some reasons to be concerned about the extent to which these training package qualifications can lead to developing practitioners who have the capabilities to critique or contest taken for granted assumptions about how the LLN field should be understood and evolve.

There has been criticism in Australia from educators about the way competency-based training and education was conceived, one being that the whole movement was driven by industry stakeholders and that educators were not involved in the early thinking about what competency-based education should look like (Gonczi 2000). Many of the educational critiques of training packages were concerned that there was little attention given to pedagogy or any educational framework for understanding how work practices are learnt. Harris and Hodge (2009:131) found in their interviews with VET educators who experienced the change to competency-based training, that they felt the imposition of new externally produced training materials posed 'an attack on the educators' profession[,] producing a resentment that lingers to this day'. Some educators argued vehemently against competency-based training and in particular, the packaging of education and training into training packages. There were analogies drawn between the itemisation of work into atomised steps in Taylorist workplaces and the compartmentalisation of work practices into atomised skills in the training packages (Hunter 2001).

The early training packages were subjected to a review by the Australian National Training Authority in 2003-2004 (Schofield and McDonald 2004 cited in Smith 2010). In relation to the critique of atomising skills, Smith (2010:58) notes:

Assessment practices in the early days were often fragmented and based on observation of work performance only (known as 'tick and flick' assessment) but there has been an effort to encourage practitioners to assess more holistically and to ensure that underpinning knowledge is adequately addressed. 
However, it is generally agreed that there remains more room for improvement in these areas.

\section{What is in the package; what is not?}

To illustrate the ways in which the training packages are organised, the names of the four core units (there are also five electives) in the new Vocational Graduate Certificate in Language, Literacy and Numeracy Practice are: Analyse and apply adult literacy teaching practices; Analyse and apply adult numeracy teaching practices; Develop English language skills of adult learners; and Implement and evaluate delivery of adult language, literacy and numeracy skills (Innovation and Business Skills Australia 2010: 6). The names of these core units are not fundamentally different to the names of some of the subjects that are in the undergraduate LLN major in the Bachelor of Education in Adult Education course that I coordinate.

Also, in the unit 'Analyse and apply adult numeracy teaching practices', for example, and using the 'Skills Recognition Guide' (Innovation and Business Skills Australia 2010) published by the Skills Council responsible for the abovementioned VET qualification as a guide to what knowledge is valued, one can see that there are assessment criteria requiring analysis with reference to theories, selection of appropriate resources and strategies, and evidence of evaluation of practice (Innovation and Business Skills Australia 2010:29). On the surface, one could argue that a qualification derived from this training package may not be all that different to what a trainee-teacher studying a university qualification can be expected to achieve. However, there are 'rules' for the design of training packages that suggest a different story. The 'rules' stipulate that knowledge should 'only be included [in a training package] if it refers to knowledge actually applied at work (DEST 2006 cited in Wheelahan 2009:231). This means that, while trainee-teachers may learn what is needed to manage the demands of the their immediate workplace contexts (or that which is assumed by the trainer to be the demands of the workplace), they may not be afforded the knowledge that can help them to contemplate alternate models of teaching and learning that have not yet been tried.

These vocational qualifications have been developed as part of the Australian Federal Government's initiative for renewal of the adult literacy and numeracy field, including its workforce. This makes it even more concerning that a capacity for future teachers to not only be unafraid to question the status quo, but also to use theoretical tools to imagine and create new possibilities for the field, may be constrained by the particular requirements of the training package design. There are tensions in 
educating workers, including teachers, who are both 'job ready', critically thinking, and imagining and creating new possibilities. However, being 'job ready' in the current adult literacy and numeracy field in both Australia and also the UK can itself stifle any creative instincts even for the 'here and now'. Black (this issue) and Tusting (2009) describe the demand on teachers to keep extensive and detailed records and be prepared for the auditors, at the expense of time they feel they ought to be spending on their teaching and learning responsibilities. Dennis (this issue) problematises defining the idea of a professional LLN practitioner in terms of what the UK Skills for Life Policy values in a practitioner. In Australia, in light of the trends in teachers' work as discussed in Black (this issue), defining a professional practitioner simply as someone who is able to do what is required of the current policy can lead an uncritical novice in the adult literacy and numeracy field to think that being a professional equates to being compliant with whatever policy is in place.

\section{Not everything can be packaged!}

What does it mean to educate teachers on the basis of a national training package? Packaging learning using detailed specifications around learning outcomes, evidence and performance criteria that ensure teachers can comply with the workplace requirements runs the risk of giving the illusion that it is teacher-proof and learner-proof; that nothing that is 'essential' is missed or mis-interpreted, or delivered and learned in a nonstandard manner. It is a form of risk management. Risk management has become an increasingly core activity in organisational life (Hutter and Power 2005), and this has led to what Power (1999) calls the audit society and Strathern (2000) calls 'audit cultures'. Audits are part of the process of risk management, to keep records and monitor compliance as a way of minimising the undesirable consequences of uncertainties that are present in any organisations or systems, including educational. Managing all the known and unknown uncertainties that might exist in a system is at best aspirational; however, even if it were possible, the end result of this may not always be desirable, particularly from the perspective of learning.

Analysing the responses of nation states to catastrophic disasters, Jasanoff (2005:210) argues that risk management can create and explain stability in groups and systems, however, in so doing makes it difficult to make or account for change, and poses challenges for learning that can be stifled through certain approaches to risk management. Her challenge can be brought to bear in the way we think about the way teacher development is managed. There may be people - presumably those who have been designing the LLN teacher training package - who believe that the competency units that constitute the package address all the skills and 
knowledge that teachers and trainers need in order to work in the current adult LLN policy environment. But policies change, because a policy is about 'the operationalization of values' and 'the power to determine what gets done' (Bell and Stevenson 2006:18, 23). When governments change, policies change. When the social, political and economic conditions change, governments exercise their power to re-prioritise their agenda to determine what is more urgent than other agendas. At this time, Australia like many countries, is facing the aftermath of a global financial crisis, and an increasingly urgent imperative to address global warming. Each of these bring challenges to the ways Australian people can imagine their own and their children's futures. What are the implications then of only presenting adult teacher-trainees with a packaged set of competencies?

Change, by definition, cannot be packaged. Neither can uncertainties. The more intractable and far-reaching the uncertainties are such as the global economic and environmental futures - the more difficult it is to know ahead of time exactly what it is to plan and prepare for. Certain types of carbon intensive jobs may disappear, resulting in a large number of displaced workers. A whole industry may collapse if producers decide to relocate their production to countries with cheaper sources of labour. New technologies and the globalisation of work can lead to the end of work practices in certain workplaces, such as the long standing team-based execution of work that depended on the sharing of skills and knowledge among the team members. Social policies can limit access to education for some, and increase it for others. Changes in immigration policies can significantly alter the socio-economic and cultural demographics in certain locations. All of these possibilities would pose challenges to individuals, their families and communities in terms of their economic wellbeing, but also their social and personal wellbeing.

If adult learning is to be valued and promoted for its wider benefits of increasing human capital, social capital and identity capital that have been demonstrated in many large and small scale studies (Schuller et al 2004, Balatti, Black and Falk 2007, Rhys Warner et al 2008, Yasukawa, Widin and Chodkiewicz 2008), then teachers of adults, particularly those who are working with the most disadvantaged groups of adults, cannot be limited by out-dated or narrowly conceived and inflexible practices. Unless teachers are going to accept that social disadvantage and exclusion are 'standard' and entirely predictable, teachers need to actively imagine and create new practices that engage learners faced with their own particular challenges in learning that in turn will help them imagine and create their own futures. Teachers need the freedom to imagine new possibilities, and trial new ideas that are based on emerging learner needs, critical inquiry and negotiation with the learner groups. The National VET Equity Advisory Council on 
developing an 'equity blueprint' to address disadvantages faced by learners suggests that much work is still needed by teachers and in policy to address the range of needs expressed by different learner groups (NVEAC 2010).

\section{From risk management to risk taking}

Teachers entering a compliance-oriented and risk-averse policy environment have a choice of becoming packaged with protective coating and adhesives to stop them from deviating into new territories or breaking out of the package and adopting what Sachs (2001, 2003 cited by Groundwater Smith and Mockler 2009:6) calls an 'activist identity', whose professionalism is characterised by acting with democratic principles, negotiation, collaboration, ability to be socially critical, a future orientation, and strategic and tactical insights. These characteristics call for teachers to have the confidence to exercise professional judgment within their practice, rather than to rely on a set of pre-determined rules and regulations to guide how they do their work. They call for courage, that according to Groundwater-Smith and Mockler (2009:32) means:

To have a concern for procedural justice;

To engage with teaching's moral purpose;

To be truly professional in undertaking practice;

To be progressive and take a transformative and libratory stance;

To tolerate ambiguity;

To have hope;

To ask difficult questions; and

To propose the challenging solutions.

Such courage is not something that is easily developed or exercised. It would be particularly difficult to develop these kinds of courage within a training regime that focused on achieving certainty and conformity with a pre-determined set of outcomes. Neither are they the kinds of competencies that appear in training packages. These qualities of courage are about having a robust understanding and commitment to democratic and social justice principles. It is about being able to show resilience when initiatives don't work the first, second or third time, and springing back again and again using whatever resources they have at hand in order to achieve what is required by one's core moral commitment. It is about not giving up on themselves or their learners because their learners haven't understood the addition of fractions, or the learners can't see why the text they have written is not formal enough for a job application, or the learners haven't quite achieved some other goal that they have negotiated. It is also about being 
able to transcend the narrow certainty and safety of the here and now to imagine alternative futures that hold greater potential for realising a more socially just world. It is about being open to possibilities so that even if the funding for the program in which the learners are enrolled is designed to improve their employability, if learning opportunity arises in the teaching and learning process that taps into the learners' broader interests or concerns, those opportunities also get taken up and capitalised upon.

What I am putting forward is not that teachers should simply rebel and refuse to comply with requirements. Rather, it is that teachers need to develop a strong sense of professional identity that is grounded in their relationship with and in their responsibility to the learners. This means being a thinking teacher who can make judgments on the pedagogical utility of particular instruments, resources and methods in the context of particular learner needs and environments, rather than be driven by the tools and rules. It means assuming the right and responsibility to question taken for granted assumptions, and to think outside the box, or perhaps, 'outside the package'.

Becoming an activist professional requires intellectual and moral strengths - attributes that are not explicitly found in training packages. It asks of the teacher-trainees to take a risk - the risk of learning not only what already exists and is known, but learning what is possible through acting upon their moral conviction and their professional judgment. It requires some of what mathematics educators Brown and Liebling (2005 citing Claxton 1999), say teachers should develop in young children to help them learn: resilience, robustness and imagination. These are attributes equally necessary for adult learners, and are qualitatively different to the kinds of competencies that can be included in a training package.

Brown and Liebling (2005) argue that resilience 'helps to develop a belief in self [that relies on having] a mature resting place, a place that can be returned to, and a flexibility that can tolerate anxiety experienced when reaching out into the unknown' (182). A blind belief in one's self without the 'mature resting place' and 'flexibility' would simply lead to arrogance and inflexibility. But teachers can be educated to engage with theories. Theories can provide explanations both of what has worked for the teachers in one instance and what has not, and more importantly, theories can help teachers to ask questions about their own practice. Through engagement with theories and asking questions, teachers can find direction in their own ongoing learning, reflection and changing practices. In an address to Australian mathematics teachers, the Australian educator Garth Boomer (1986:4) argued the need for teachers to have a sound theoretical underpinning to their practice: 
While teachers operate at an intuitive level as pragmatists, not articulating to themselves the present theory which drives their practice, they are effectively paralysed in terms of their capacity to change radically. The non-theorised practitioner is a kind of well-intentioned misguided or unguided missile in the classroom likely to take up a new idea and add it to the repertoire but unable to generate infinite practice for new contexts.

Wheelahan (2009), in her critique of competency-based approach in VET, shares the concerns that Boomer expresses above about the 'unguided missile'. She argues that competency-based training in Australia gives VET learners access to 'contextually specific applications of knowledge, and not the system of meaning in which it is embedded' (231). She uses Bernstein's sociology of knowledge to say that teachers who are trained within a competency-based framework are taught the skills and knowledge to manage the 'here and now' - what Bernstein calls 'horizontal discourse', but are denied the abstract theoretical knowledge - what Bernstein calls 'vertical discourse' - in which the integration of knowledge occurs through the integration of meanings and not through relevance to specific contexts' (Wheelahan 2009:230). One needs to be concerned about whether this limitation of competency-based training will be evident when the new VET qualifications for LLN teachers are implemented.

The practitioner who can make informed decisions rather than one who unquestioningly sticks to rules or gets lured to anything new and different has to have a robust sense of purpose in what they are doing. The aims of the curriculum they are using may be written down on paper, but the reason why the teacher is involved in the education of adults has to have a deeper and a more personal conviction than something that can be externally specified. This conviction is what teachers will need to draw on to sustain their practice, to make sense of and learn from set backs and errors, as well as successes that teachers will experience in their work.

If teachers have a robust sense of purpose in their work, then they also need to be able to imagine new possibilities when the theories, past experiences and common sense do not appear to be helping them achieve their purpose. No 'tool kit' that they can gain - from a VET training package or even a university teacher education course - can sustain a teacher who sees teaching as a dialogic, relational practice that derives meaning through the connections teachers make with their learners. Hence what the preparation of teachers ought to do is to provide them with the spaces and places for them to examine what they know, to ask questions and to create new understandings and knowledge through critical inquiry with other practitioners. 


\section{Conclusion - how risky is risk taking?}

Learning the practice of teaching beyond what is prescribed in the 'risk-management' package is risky. Mistakes might be made. Some 'essentials' might be left off. Some requirements may not be able to be accounted for. And these pose real risks for teachers whose employment has become increasingly precarious, and whose employers have to win competitive tenders to get funding to deliver programs. I am not arguing that teachers should risk their livelihood or their employers' funding sources. Nor am I in a position to pre-judge the quality of the teacher preparation that can be achieved through the new VET teaching qualifications. At the same time, I think that giving up the struggle to find places and spaces for teachers to engage in critical inquiry to change and develop their practices in order that their learners can change and grow is unconscionable as a teacher educator.

Although the position I am taking on teachers' professional development can easily be criticised and dismissed as self-serving - after all, I coordinate and teach in an adult education teacher development program at a university - there is one key feature of the university environment that deserves attention when we (LLN teacher educators in universities as well as other stakeholders in the field of LLN) are debating where the education of teachers can or should take place. Universities, at least in Australia, have a mandate to engage in and promote open and critical inquiry and both students and academic staff are protected by the principles of academic freedom. If teacher-trainees are going to be exposed to a critical analysis of current theories and practices, they and those who are teaching them must be part of a community of scholars who can safely and productively engage in this kind of inquiry. It is also important that the university academics are guiding the teacher-trainees in an informed critical analysis that recognises the history and the social and political contexts of the current policy contexts that are influencing teachers' practices. It is through this kind of collective inquiry that new knowledge and new practices can emerge, and teachers as a collective can begin to imagine productive change. There is a mandate for university LLN teacher education academics to renew their engagement in the provision of programs that give space for teacher-trainees with vision and a willingness to explore new possibilities.

\section{References}

Australian Bureau of Statistics (2008) Adult Literacy and Life Skills Survey, Summary of Results, Commonwealth of Australia, Canberra. 
Balatti, J, Black, S and Falk, I (2007) Teaching for Social Capital Outcomes: The case of adult literacy and numeracy courses, Australian Fournal of Adult learning, vol. 47, no. 2, pp. 245-263.

Bell, L and Stevenson, H (2006) Education Policy: Process, themes and impact, Routledge, London.

Boomer, G (1986) From Catechism to Communication: Language, Learning and Mathematics, Australian Mathematics Teacher, 42 (Apr), pp 2-7.

Brown, T and Liebling, H (2005), The Really Useful Maths Book: A guide to Interactive Teaching, Routledge, London.

Gonczi, A (2000), Review of International Trends and Developments in Competency-based Education and Training, in Arguelles, G and Gonczi, A, Eds, Competency Based Education and Training: A world perspective, Noriega, Balderas, Mexico, pp 15-39.

Groundwater-Smith, S and Mockler, N (2009), Teacher Professional Learning in an Age of Compliance: Mind the gap, Springer, Milton Keynes.

Harris, R and Hodge, S (2009) A Quarter of a Century of CBT: The vicissitudes of an idea, International fournal of Training Research, vol 7, no 2, pp 122-133.

Harrison, D (2009) 'Poor Literacy at Work Costing Millions', The Sydney Morning Herald, 30 August, accessed 30 August 2009 at http://www.smh.com.au/national/poor-literacy-at-work-costingmillions-20090830-f3z0.html

Hunter, J (2001) Training Packages: The scientific management of education, in Research to Reality: Putting VET Research to Work: Proceedings of the Australian Vocational Education and Training Research Association (AVETRA) Conference, Adelaide, retrieved 28 Nov 2010 from http://avetra.org.au/publications/conference-archives/conferencearchives-2001/2001-papers

Hutter, B and Power, M, eds (2005) Organisational Encounters with Risk, Cambridge University Press, Cambridge.

Innovation and Business Skills Australia (IBSA) (2010) User Guide for TAE70110 Vocational Graduate Certificate in Language, Literacy and Numeracy Practice, TAE80110 Vocational Graduate Certificate in Language, Literacy and Numeracy Leadership, Innovation and Business Skills Australia Ltd, East Melbourne.

Jasanoff, S (2005) Restoring Reason: Causal narratives and political culture, in B. Hutter \& M. Power (eds), Organisational Encounters with Risk, Cambridge University Press, Cambridge.

Job, P (2010) Language, Literacy and Numeracy Programs under Threat, The Australian TAFE Teacher, Winter, p15.

Mackay, S, Burgoyne, U, Warwick, D and Cipollone, J (2006) Current and future professional development needs of the language, literacy and numeracy 
workforce, National Centre for Vocational Education Research, Adelaide.

McGuirk, J (2001) Adult literacy and numeracy practices 2001: A national snapshot, TAFE New South Wales Access Division, New South Wales Department of Education and Training, Sydney.

Naidu, R (2008) VET glossary, National Centre for Vocational Education and Training, Adelaide, South Australia.

National VET Equity Advisory Council (NVEAG) (2010) Equity Blueprint: Creating futures: Achieving potential through VET, TVET Australia, Melbourne.

Nechvoglod, L, Mlotkowski, P and Guthrie, H (2010) National TAFE Workforce Study 2008, National Centre for Vocational Education Research, Adelaide.

Power, M (1999) The Audit Society: Rituals of Verification, Oxford University Press, Oxford.

Schuller, T, Preston, J, Hammond, C, Brassett-Grundy, A and Bynner, J, (eds) (2004) The Benefits of Learning: The impact of education on health, family life and social capital, Routledge, Falmer, London.

Skills Australia (2010) Australian Workforce Futures: A National Workforce Development Strategy, Commonwealth of Australia, Canberra.

Smith, E (2010) A Review of Twenty Years of Competency-based Training in the Australian Vocational Education and Training System, International Fournal of Training and Development, vol 14, no 1, pp 54-64.

Strathern, M, Ed (2000) Audit Cultures, Routledge, London.

Rys Warner, J, Vorhaus, J, Appleby, Y, Bathmaker, A-M, Brooks, G, Cole, P, Pilling, M, and Pearce, L (2008) The Learner Study: The Impact of the Skills for Life strategy on adult literacy, language and numeracy learners,

National Research \& Development Centre for adult literacy and numeracy, London.

Tusting, K (2009) "I am not a good teacher; I don't do all their paperwork": Teacher resistance to accountability demands in the English Skills for Life Strategy, Literacy and Numeracy Studies, vol 17, no 3, pp 6-26.

Wheelahan, L (2009) The Problem with CBT (and why constructivism makes things worse), Fournal of Education and Work, vol 22, no 3, pp 227-242.

Yasukawa, K, Widin, J and Chodkiewicz, A (2008) The Benefits of Learning Numeracy, J. Matos, P. Valero \& K. Yasukawa (Eds) Proceedings of the Fifth International Mathematics Education and Society Conference, Albufeira, Portugal 16 ${ }^{\text {th }}-21^{\text {st }}$ February, 2008, pp 495-504. 